\title{
60Sn-40Pb はんだ材の粘塑性変形* (ひずみ速度効果の記述)
}

\author{
大口健 一*1, 佐々木 克彦*2, 石川博 將*2
}

\author{
Viscoplastic Deformation of $60 \mathrm{Sn}-40 \mathrm{~Pb}$ Solder Alloys \\ (Description of Strain Rate Effect)
}

\author{
Ken-ichi OHGUCHI, Katsuhiko SASAKI and Hiromasa ISHIKAWA
}

\begin{abstract}
In this paper, we discuss the viscoplastic deformation and the constitutive model of $60 \mathrm{Sn} 40 \mathrm{~Pb}$ solder alloys which is used for the connection of electronic packaging. The constitutive model is developed with the concept that the deformation includes the elastic, plastic, and creep deformation. which is caused from the strain rate effect on the deformation of the solder alloys. Namely, the constitutive model proposed in this paper combines the cyclic plastic model for the time independent part of deformation with the Norton's creep one for the time dependent part. The applicability of the model is verified from the comparison of the simulations based on the model for a series of tests, such as a pure tension and a cyclic loading under several strain rates. As a result, the constitutive model can predict the essential futures of the time dependent deformation of $60 \mathrm{Sn}-40 \mathrm{~Pb}$ solder alloys.
\end{abstract}

Key Words : $60 \mathrm{Sn} 40 \mathrm{~Pb}$ Solder Alloys, Viscoplasticity, Creep, Cyclic Loading, Strain Rate, Constitutive Model, Electronic Packaging

\section{1. 緒言}

電子回路装置の小形化，多機能化のための高密度実 装技術として，微細はんだ接続が広く用いられてい る.多数の LSI チップが装着された実装基板は，材料 特性の暴なる微小材料から構成されている。したがっ て, 実際の使用環境下で㳘，LSI 自身の自己発熱や冷 却などによる雾国気温度の変化と微小材料の熱膨張率 の違いによる熱変形量の差から，微小材料を接続して いるはんだ材に応力が生ずる。また，渑源のオン・オ フ，基盤の冷却などの温度変動妿闪により，この伈 は繰返し作用する。このように，接続用はんだ材は， 力学的に著しく蕨しい使用環境下に筒かれている。こ のため、はんだ材の基本的な力学特性および疲学特性 在把提し，疫学寿命䚵価法を奏験的・理論的に確立す ることが急務となっている。

現在までにも，はんだ材の力学特性・波学特性を実 験的に把握する研究が行れれている。例えば Solomon ${ }^{(1)}$ は、はんだ材け繰返し変形特性と瘦労寿命

* 原稿受付 1996 年 71110 11

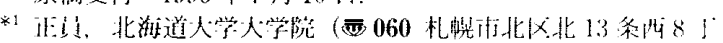
11).

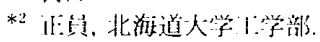

の㝬験的考察を行い，Coffin-Manson 則を用いた波労 寿命予測を試みている，Guoら(2)は，㑭街中にひずみ 速度変化，または，温度变化がある場合の95.5 Sn 4 $\mathrm{Cu} 0.5 \mathrm{Ag}$ 材の変形挙動の考察を行い, その変形機構 の解明を試みている。さらに，著者ら峰前報(3)で，塑 性ひずみ仕事率密度の概念を提案し，ひずみ速度，霖 四领温度などの負荷条件が異なる疲労寿命を予測でき る披学寿命評価法を $60 \mathrm{Sn}-40 \mathrm{~Pb}$ 材による央験上繰这 し粘塑性構成式加的確立している。

また，材料の粘塑性変形を䛉述する理論的研究も数 多く行われている。例えば，抈中ら(4)(5)は，温度变動 腰歴の非弾性举動への影響を考虑した統一形構成式の 構築を試みている。さらに, Freed ら ${ }^{(6)}$ は，温度変化 存考虑した粘塑性構成式に関する検討を行い，Ohno らは（時効効果とクリープに関卞る理論解析につい て検討している，河井(8)は，塑性ひずみとクリープの 暴今性との閔連性について理諭的検討を行っている。 また，Leeら ら ${ }^{(9)}$ ，過忍力の概念に基づく粘塑性構成 式老温度変化在伴う変形解析に忍用している。

类装基板トではんだ材に作用蛮る負荷では，ひずみ 速度は一定でなく，な扔かつ，温度変化が伴うことが 推察できる。さらに、はんだ材は，ひずみ速度低存性 揖よび温度依存性が鋼などの一般金属材料と比較する 
と渚しい(3). 著者らが先に提案した披労寿命評価法:(3) を実装状態に拉張し、構造解析などによるより適正な 疲労寿命評価を行うためには，負荷中のひずみ速度変 化㧍上び温度变化に対心できるはんだ材の力学的構成 モデルが必要である。しかしながら，現在までに，負 荷の途中でひずみ速度が变化した場合に見られる特徵 的な梳んだ材の心力ーひずみ関係を正確に記述できる 簡便な構成モデルはほとんどない。

そこで本研究では，ひずみ速度変化や温度変化を伴 う負荷を記述可能な構成式の構築の第一段階として, まずひずみ速度効果にのみ着目し，はんだ材の著し いひずみ速度依存性による特街的な变形举動を的確に 記述できる構成モデルの構築を行う。はんだ材の変形

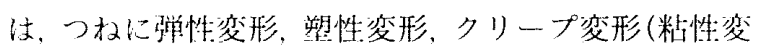

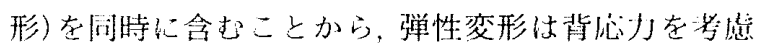
した Hookeの法則より, 塑性变形は Mises の降伏条 件と Prager Zieglerの移動硬化则より,クリーブ変 形はNorton 则よりそれぞれ求め，全体のひずみをそ れらの利で表して構成モデルを構筑する。つまり、構 成式の枠組は古典的手法であるが，上述の3 種類の変 形様式が移動硬化則より定まる背応力を介し，逨結さ れているのが本モデルの特徴である。そして, その適 用性を60 Sn $40 \mathrm{~Pb}$ はんだ材を用いたしひずみ速度の

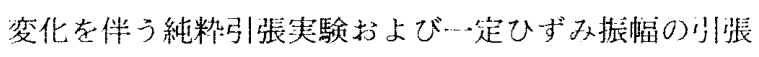
り・止:縮実験により検討寸る。

\section{2. 実 験 方 法}

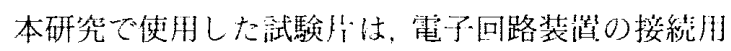
はんだとして使用される60 Sn 40 Pb材である。60 $\mathrm{Sn}-40 \mathrm{~Pb}$ 材络, Snと $\mathrm{Pb}$ が $60: 40$ の重量比から成っ ている。試験片の形状は直径 $5 \mathrm{~mm}$, 標点間距離 20 $\mathrm{mm}$ の中失门样である、陚験片の製作は，実際の電子 问路装置のはんだ接続部の鋳造状態を考慮する必要が 苟るため，黒鉛製の鋳型に溶融した前述の重量制合の $\mathrm{Sn}$ と $\mathrm{Pb}$ を流し込み, 自然空冷状態で冷却する方法で 行い，試験忛は，残留忠力を除去するため，鋳造後 2 週間室温で放置した後，実験に使用した(3)。また，試 験機は, 引張り・王縮試験機 (Instron 社製

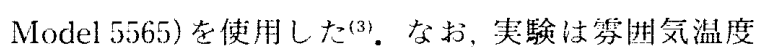
を試験機付届の恒温槽により一定に保って行った。

专ず，構成モデルの構築扔よび材料定数の決定のた わの基碗実験として、クリープ夷験と 3 種類のひずみ 速度 $0.001,0.01,0.1 \% / \mathrm{s}$ での純粋引張実験および一 定ひずみ振幅 $0.5 \%$ での引張り・厈縮繰返し負荷実験 を行った。次いで，構成モデルの速度依存性への適用

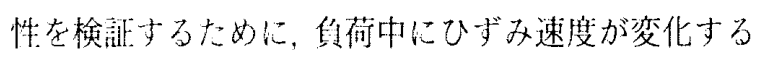

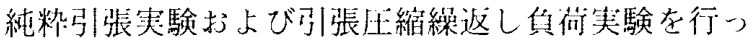

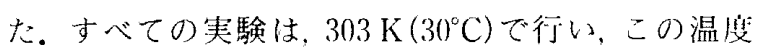
トでの試験片の縦弾性係数は 10.7 GPa であった ${ }^{(3)}$. な扔, 温度变動トでの温度効果の䛉述については別報 にて発表予定である。

\section{3. 構成 モ デル}

$3 \cdot 1$ 全ひずみ増分および弾性ひずみ增分 本研 究では，まず，以下の伋先を適用与る。（1）60 Sn 40 $\mathrm{Pb}$ はんだ材の上うな著しいひずみ速度低份性在示与 材料の変形には，一权に時間非低存成分である弾性变 形，塑性变形と特間低有成分であるクリーナ゙変形が间 牊に命まれている。（2）弾性ひずみ增分，塑性ひずみ 增分，クリーブひずみ增分の力问はつ权に共軸であ 3。(3) 非弹性変形(塑性変形、クリーブ变形)により

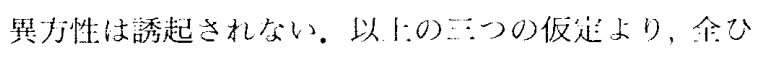
ずみ增分テンソルは，弾性ひずみ增分テンソル，塑性 ひずみ增分テンソル、クリーブひずみ增分テンンルの 和として次式で表せ放机る。

$$
d e_{i j}=d e_{i j}^{e}+d \varepsilon_{i j}^{p}+d \varepsilon_{i j}^{c} \cdots
$$

式（1）で，de $e_{i j}$ は全ひずみ增分り偏差成分であり， $d e_{i j}^{e}$ は $d e_{i j}^{e}=d \varepsilon_{i j}^{e}-d \varepsilon_{k k}^{e} \delta_{i j} / 3$ で表せら机る弾性ひずみ 增分り偏差成分である。d祸は塑性ひず增分であ

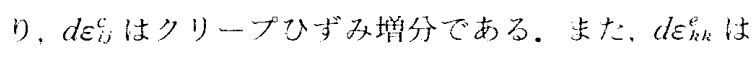
静水止: $d \sigma_{k k}$ と次式の関係がある。

$$
d \varepsilon_{k k}^{e}=\frac{d \sigma_{k k}}{3 \kappa}
$$

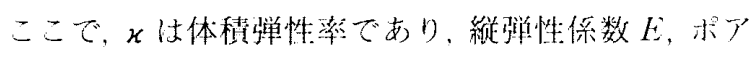

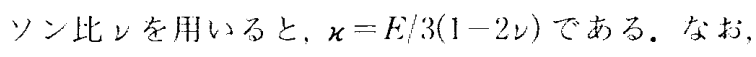

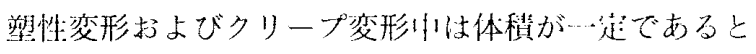
いう非正縮性の仮运から，塑性とクリーブひずみ增分 の軸力向成分の私 $d \varepsilon_{k k}^{p}$ および $d \varepsilon_{k n}^{k}$ はともに业であ る、したがって，式（1）に式（2）を教煌す札ば全ひず み增分 $d \varepsilon_{i,}$ が算!岁さる。

等力性材料刘して，塑性変形中に扔いて背伈力を 新たな负荷原点として考虑すると，単性ひずみ增分を 次玕の Hooke の法則により算虾できる。

$$
d c_{i j}^{e}=\frac{d s_{i j}-d b_{i j}}{2 / 1}
$$

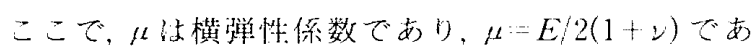

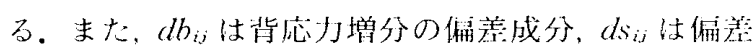

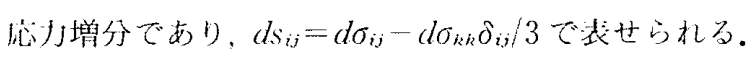

$3 \cdot 2$ 塑性ひずみ增分 塑性ひずみ增分は, 巟に 薯者らが行った下記の綝返し塑性構成モデル(10)が

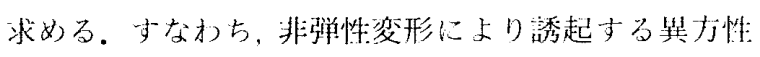

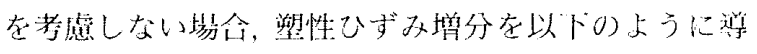


出できる.

まず, 背応力を考慮した von Mises の降伏条件よ り，相当応力 $\bar{\sigma}$ を次式で定義する.

$$
\bar{\sigma}=\left\{\frac{3}{2}\left(s_{i j}-b_{i j}\right)\left(s_{i j}-b_{i j}\right)\right\}^{1 / 2}
$$

ここで， $b_{i j}$ は背応力の偏差成分である．さらに，負荷 関数を相当応力を用いて次式で定義する.

$$
f=\bar{\sigma}-R
$$

ここで， $R$ は流れ応力である. 式(5)と，降伏曲面と 塑性ひずみ増分の垂直性の仮定より，塑性ひずみ増分 $d \varepsilon_{i j}^{p}$ は次式で与えられる.

$$
d \varepsilon_{i j}^{p}=\frac{3}{2} \frac{d \bar{\varepsilon}^{p}}{\bar{\sigma}}\left(s_{i j}-b_{i j}\right)
$$

式 (6)で， $d \bar{\varepsilon}^{p}$ は相当塑性ひずみ增分である.

今, 相当塑性ひずみ $\bar{\varepsilon}^{p}$ と相当応力が次式で表せる と仮定する。

$$
\bar{\varepsilon}^{p}=\frac{K}{E}\left\{\frac{1}{D}\right\}^{m} \bar{\sigma}^{m+1}
$$

ここで, $K$ は定数であり， $D$ は抗応力， $m$ は硬化指数 である．硬化，軟化安定材の応力ーひずみ関係は，繰返 し負荷により安定し，一定のループを描くという英験 事実(11) に基づき， $D$ ，および $m$ はそれぞれ次式によ り表せる(12) と仮定する。

$$
\begin{aligned}
& D=D_{0}\left\{1-\alpha \exp \left(-\frac{p}{c_{1}}\right)\right\} \\
& m=m_{0}\left\{1-\beta \exp \left(-\frac{p}{c_{2}}\right)\right\}
\end{aligned}
$$

式(8)，(9)で, $D_{0}, \alpha, c_{1}, m_{0}, \beta, c_{2}$ は材料定数であ る.また， $p$ は，前負荷まで，すなわち， $n$ 回めの負荷 方向の変化を受けるまでに累積された塑性ひずみ $\int_{(n-1)} d \bar{\varepsilon}^{p}$ であり, 現負荷方向中は一定值である.

式（7）の両辺を微分すると, 相当塑性ひずみ増分は 次式で与えられる。

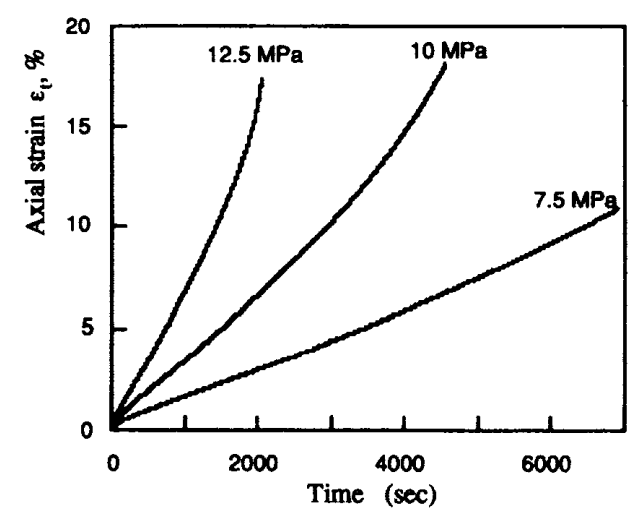

Fig. 1 Creep curves

$$
d \bar{\varepsilon}^{p}=\frac{K}{E}(m+1)\left\{\frac{\bar{\sigma}}{D}\right\}^{m} d \bar{\sigma}
$$

式（4），(6)，(10)より，最終的に次式の塑性ひずみ 增分を得る。

$$
\begin{array}{r}
d \varepsilon_{i j}^{p}=\frac{3 B}{2}\left\{\frac{\bar{\sigma}}{\bar{D}}\right\}^{m} \frac{1}{\bar{\sigma}^{2}}\left(s_{i j}-b_{i j}\right)\left(s_{k l}\right. \\
\left.-b_{k l}\right)\left(d s_{k l}-d b_{k l}\right) \cdots \cdots \ldots \ldots \ldots \ldots
\end{array}
$$

ここで, $B=3 K(m+1) / 2 E$ である.

背応力は, 次式の Prager-Ziegler の移動硬化則を 用いて定めた。

$$
d b_{i j}=\left(s_{i j}-b_{i j}\right) d \chi
$$

式(12)で $d \chi$ は定数である. 式(12)と Prager $の$ 適合 条件 $d f=0$ および塑性仕事増分 $d W^{p}=\left(s_{i j}-b_{i j}\right) d \varepsilon_{i j}^{p}$ $=\bar{\sigma} d \bar{\varepsilon}^{p}$ の関係より，背応力增分は次式で表される.

$$
\begin{array}{r}
d b_{i j}=\frac{3}{2 \bar{\sigma}^{2}}\left\{\left(s_{i j}-b_{i j}\right)\left(s_{k t}-b_{k l}\right) d s_{k l}\right\} \\
-\frac{d R}{\bar{\sigma}}\left(s_{i j}-b_{i j}\right) \ldots \ldots \ldots \ldots \ldots \ldots \ldots \ldots \ldots \ldots \ldots \ldots \ldots \ldots \ldots
\end{array}
$$

さらに, $D, m$ と同様に, 流れ応力 $R$ が次式で表せる と仮定する。

$$
R=R_{0}\left\{1-\lambda \exp \left(-\frac{p_{a}}{c_{3}}\right)\right\}
$$

ここで， $R_{0}, \lambda, c_{3}$ は材料定数である．また， $p_{a}$ は負荷 方向の変化にかかわらず現負荷中在含めた紫積塑性ひ ずみ $\int d \bar{\varepsilon}^{p}$ である。雾囲気温度が一定の場合, 式(14) の両辺を微分すると次式を得る。

$$
d R=\frac{1}{c_{3}}\left(R_{0}-R\right) d \bar{\varepsilon}^{p}
$$

したがって，式(13)，(15)より，背応力堌分は最終的 に次式となる。

$$
\begin{aligned}
d b_{i j} & =\frac{3}{2 \bar{\sigma}^{2}}\left\{\left(s_{i j}-b_{i j}\right)\left(s_{k l}-b_{k l}\right) d s_{k l}\right\} \\
& -\frac{1}{c_{3} \bar{\sigma}}\left(R_{0}-R\right)\left(s_{i j}-b_{i j}\right) d \bar{\varepsilon}^{p} \ldots \ldots
\end{aligned}
$$

なお, 背灾力は負荷方向の変化がない場合, その筫 荷中は一定值である。すなわち，負荷方向が変化する と, 負荷方向が変化した瞬間の背忍力の值を新たな原 点として適用し，次の負荷を計算寸る。

$3 \cdot 3$ クリープひずみ増分 本研究で扱う $60 \mathrm{Sn}$ $40 \mathrm{~Pb}$ はんだ材の $303 \mathrm{~K}$ でのクリープ曲線を図1に示 す. 図 1 は, 3 種類 $一$ 一定負荷 $7.5 \mathrm{MPa}, 10 \mathrm{MPa}$, $12.5 \mathrm{MPa}$ においてクリープ武験を行ったときの結果 である。いずれの一定荷重下においても，遷移クリー プ領域がほとんど見られず，定常クリープと加速クリ ープのみでクリープ曲線が構成されていることが図 1 よりわかる。このことは，ある一定応力何重ドで微小 時間内に生じる $60 \mathrm{Sn}-40 \mathrm{~Pb}$ はんだ材のクリープひず みが，定常クリープ則で表示できることを示してい 
る。そこで，微小時間内に発生するクリープひずみが， 次式の Norton 則(5)(そ)で表示できると仮定する.

$$
\dot{\varepsilon}_{i j}^{c}=\frac{3 A}{2} \bar{\sigma}^{n-1}\left(s_{i j}-b_{i j}\right)
$$

上式で $\dot{\varepsilon}_{i j}^{c}$ は, クリープひずみ速度, $A, n$ は材料定数 である. 式(17)より, 微分時間 $d t$ 中に生ずるクリー プひずみ増分は次式となる。

$$
d \varepsilon_{i j}^{c}=\frac{3 A}{2} \bar{\sigma}^{n-1}\left(s_{i j}-b_{i j}\right) d t
$$

\section{$3 \cdot 4$ クリープ変形を考虑した粘塑性構成モデル} 式（1）に式(3)，(11），(18）を代入すると次式を得る.

$$
\begin{gathered}
d e_{i j}=\frac{d s_{i j}-d b_{i j}}{2 \mu}+\frac{3 B}{2}\left(\frac{\bar{\sigma}}{D}\right)^{m} \frac{1}{\bar{\sigma}^{2}}\left(s_{i j}-b_{i j}\right)\left(s_{k i}\right. \\
\left.-b_{k l}\right)\left(d s_{k l}-d b_{k l}\right)+\frac{3 A}{2} \bar{\sigma}^{n-1}\left(s_{i j}-b_{i j}\right) d t
\end{gathered}
$$

ところで，ある全ひずみ速度 $\dot{e}_{i j}$ で負荷をする場会， 微小時閶 $d t$ 中に生ずる全ひずみ増分 $d e_{i j}$ は $\dot{e}_{i j} d t$ で 表される。また，応力增分 $d s_{i j}$ は，全ひずみ速度 $\dot{e}_{i, j}$ に起因する応力速度を $\dot{s}_{i j}$ とすると， $\dot{s}_{i j} d t$ で表され なければならない。したがって，式(19)は次式のひず み速度と忍力速度の関係となる。

$$
\begin{gathered}
\dot{e}_{i j}=\frac{\dot{s}_{i j}-\dot{b}_{i j}}{2 \mu t}+\frac{3 B}{2}\left\{\frac{\bar{\sigma}}{D}\right\}^{m} \frac{1}{\bar{\sigma}^{2}}\left(s_{i j}-b_{i j}\right)\left(s_{k l}-b_{k l}\right) \\
\quad \times\left(\dot{s}_{k l}-\dot{b}_{k l}\right)+\frac{3 A}{2} \bar{\sigma}^{n-1}\left(s_{i j}-b_{i j}\right) \cdots \cdots \cdots(20)
\end{gathered}
$$

また，同様に背応力增分は式(16)，(10)より次式とな る.

$$
\begin{aligned}
\dot{b}_{i j} & =\frac{3}{2 \bar{\sigma}^{2}}\left\{\left(s_{i j}-b_{i j}\right)\left(s_{k l}-b_{k l}\right) \dot{s}_{k l}\right\} \\
& -\frac{B}{c_{3} \bar{\sigma}^{2}}\left(R_{0}-R\right)\left(s_{i j}-b_{i j}\right)\left\{\frac{\bar{\sigma}}{D}\right\}^{m} \\
& \times\left(s_{k l}-b_{k l}\right)\left(\dot{s}_{k l}-\dot{b}_{k i}\right) \quad \ldots \ldots \ldots . .
\end{aligned}
$$

寸なおち，式(20)，(21）が，本構成モデルの基本式 である。

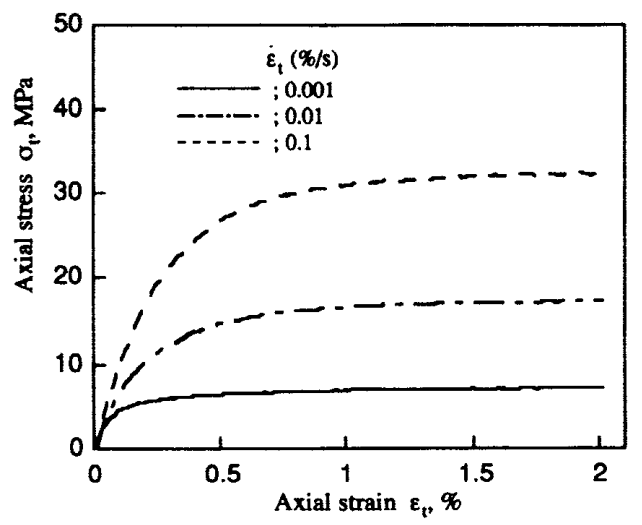

Fig. 2 Pure tension (experiment)

\section{4. シミュレーション結果および考察}

$4 \cdot 1$ 単軸負荷への適用 純䊉引張筫荷および引 張り・圧縮繰返し負荷に 3 章の構成モデルを適用する ために，まず，式（2）を考虑して，式(20)，(21)を単軸 状態に書き換えるとそれぞれ次式となる。

$$
\begin{aligned}
\dot{\varepsilon}_{t} & =\frac{\dot{\sigma}_{t}-\dot{b}_{t}}{E}+\frac{2 B}{3}\left\{\frac{\sigma_{t}-b_{t}}{D}\right\}^{m}\left(\dot{\sigma}_{t}-\dot{b}_{t}\right) \\
& +A\left|\sigma_{t}-b_{t}\right|^{n} \operatorname{sgn}\left(\sigma_{t}-b_{t}\right) \cdots \cdots \cdots \cdots \cdots \cdots \cdots \cdots \cdots \cdots \cdots \\
\dot{b}_{t} & =\dot{\sigma}_{t}-\frac{2 B}{3 c_{3}}\left(R_{0}-R\right)\left\{\frac{\sigma_{t}-b_{t}}{D}\right\}^{m}\left(\dot{\sigma}_{t}-\dot{b}_{t}\right)
\end{aligned}
$$

式(22)，(23)で， $\varepsilon_{t}, \sigma_{t}, b_{t}$ はそれぞれ単軸ひずみ, 単 軸少力，単軸の背応力である。また, $\operatorname{sgn}(x)$ は, 変数 $x$ が正の時は +1 , 負のときは -1 を与える関数であ 万.

背忘力を考虑して変形をシミュレーションする場 合, 負荷の方向が変化した瞬間の背応力が次の負荷力 向をシミュレーションするための原点として適用され

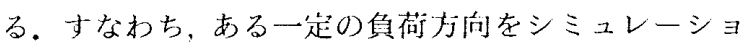
ンしている間は，その適用原点(背応力)は変化しな

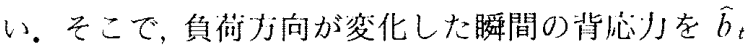
で表し，現負侕中で $\dot{\vec{b}}_{t}=0$ を考慮すると，式(22)， (23)はそれぞれ次式となる。

$$
\begin{aligned}
\dot{\varepsilon}_{t} & =\frac{\dot{\sigma}_{t}}{E}+\frac{2 B}{3}\left\{\frac{\sigma_{t}-\hat{b}_{t}}{D}\right\}^{m} \dot{\sigma}_{t} \\
& +A\left|\sigma_{t}-\hat{b}_{t}\right|^{n} \operatorname{sgn}\left(\sigma_{t}-\hat{b}_{t}\right) \quad \cdots \cdots . . \\
\dot{b}_{t} & =\dot{\sigma}_{t}-\frac{2 B}{3 c_{3}}\left(R_{0}-R\right)\left\{\frac{\sigma_{t}-\hat{b}_{t}}{D}\right\}^{m} \dot{\sigma}_{t}
\end{aligned}
$$

ところで, 式(24)の右辺第3項めは定常クリープを 表す Norton 則である。ここで用いら机る定数 $A$ お よび $n$ を実験から簡単に定めシミュレーションに用 いるために, 定数 $A$ および $n$ に関して以下のような 処理を行った。

図 2 は，3種類のひずみ速度 $0.001,0.01,0.1 \% / \mathrm{s}$ で純粋引張試験を行ったときの結果であり，それぞれ の応力ーひずみ関係を実線, 一点鎖線, 破線で示してい る。図 2 より明らかなように，はんだ材の場合は、一 般金属材料と比較すると加工硬化が小さく，なおかつ， 一定応力でひずみが進行するひずみ範囲が存在する。

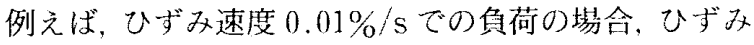
が約 $1.3 \%$ で応力增分が笭になり，ひずみ $1.3 \%$ 以降 は一定応力 (16.7 MPa)でひずみが進行古る。また， その一定応力の傎は，与えるひずみ速度により著しく 異なる，そこで，この一定応力と与えたひずみ速度 $\dot{\varepsilon}_{0}$ の関係が, Norton 則と同様な次式の関数で表示で きると仮定した。 
$\dot{\varepsilon}_{0}=A_{0} \sigma_{\mathrm{lim}}^{n^{\prime}}$

ここで， $\sigma_{\lim }$ は純粋引張試験において応力増分が零に なる一定忍力值であり， $A_{0}, n^{\prime}$ は定数である.

さらに，繰返し負荷時の一定応力 $\sigma_{11 \mathrm{~m}}$ は以下゙のよう に仮定する。図 3 に, 一例として，ひずみ速度 $0.01 \% / \mathrm{s} て ゙ の$ 純粋引張実験の応力ーひずみ関係と, 純 粋引張実験と同一のひずみ速度での引張り・王縮繰返 し夋何実験での硬化安定時の引張側の応力ーひずみ関 係との比較を示寸。図 3 では比較のために，繰返し积 荷実験での忍少ひずみ関係のひずみの值を原点にシ フトして表示している. 図 3 から明らかなように, 純 粋引張実験で見られる一定忘力做が, 繰返し鱼荷安定 時の圭力ひずみ関係でも存在し，それらの值はほほ 等しい。このことから，引張り・圧縮繰返し負荷の場 合も背応力を考虑すれば, 式(26) と同様に一定応力值 とひずみ速度の関係を次式のように表せられると仮定 できる。

$$
\dot{\varepsilon}_{0}=A_{1}\left(\sigma_{\mathrm{llm}}-\hat{b}_{t}\right)^{n^{\prime \prime}}
$$

上式で $A_{1}, n^{\prime \prime}$ は定数である。ここで, 簡単化のため に $n^{\prime}=n^{\prime \prime}=n$ とすると, 式(26)，(27)より定数 $A_{1}$ は 次式で与えられる。

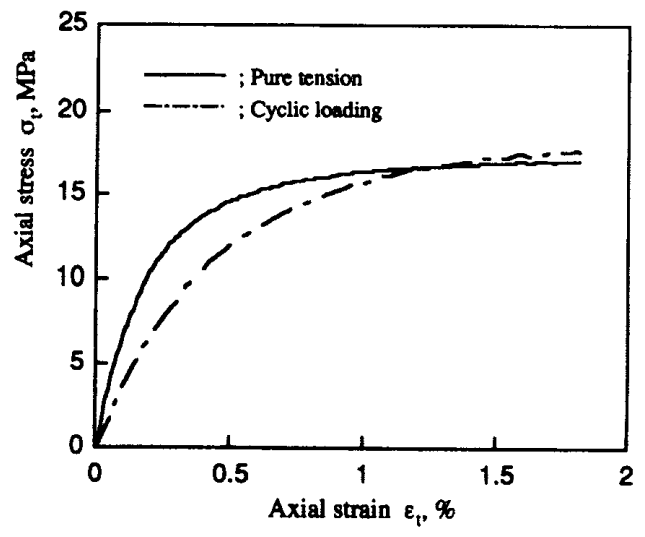

Fig. 3 Comparison of pure tension with cyclic loading

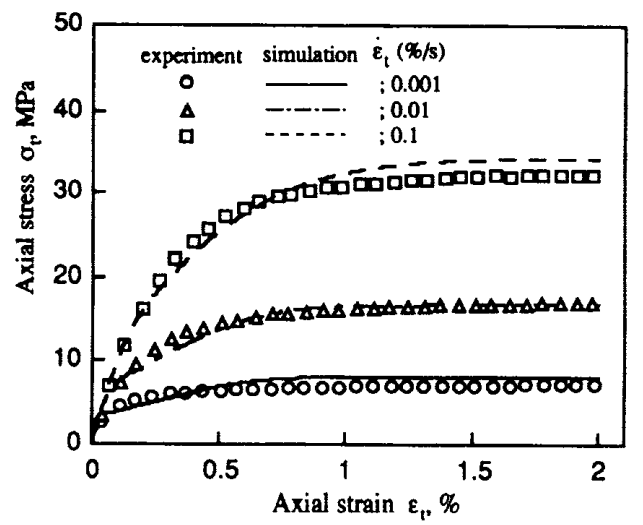

Fig. 4 Simulation of pure tension

$$
A_{1}=\left(\frac{\sigma_{1 \mathrm{~m}}}{\sigma_{\mathrm{llm}}-\bar{b}_{t}}\right)^{n} A_{0}
$$

また, 式(28)の $A_{1}$ は, 応力ーひずみ関係が一定応力

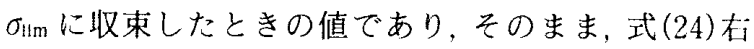
辺第 3 項めの定数 $A$ と同值として扱うことがでさな い. そこで, 式 (24) 右辺第 3 項めの定数 $A$ が, 適用原 点のひずみ(背応力に対応するひずみ) $\varepsilon_{t}^{b}$ からのひず みの大きさ $\left|\varepsilon_{t}-\varepsilon_{t}^{b}\right|$ の増加に伴い， $A_{1}$ に収束すると し,さらに, 式(28)を用いて次式で表せると仮定する。

$$
A=\left\{1+C \operatorname{cxp}\left(-\frac{\left|\varepsilon_{t}-\varepsilon_{t}^{b}\right|}{C_{4}}\right)\right\}\left(\frac{\sigma_{1 ! m}}{\sigma_{1 \mathrm{lim}}-\widetilde{b}_{t}}\right)^{n} A_{0}
$$

上式で, $C, C_{4}$ は定数である.

$4 \cdot 2$ 純粋引張りおよび一定ひずみ振幅引張り・圧 縮繰返し負荷 図 4 に, 純粋引張時の応力ーひずみ 関係のシミュレーション結果を亦す. 図 4 で実線, 一 点鎖線，破線はそれぞれひずみ速度 $0.001,0.01$,

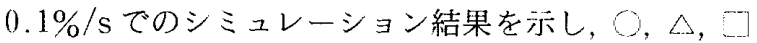
印は図 2 の実験結果を示している. 図 4 でシミュレー ション結果は奏験結果をほぽよく表しているが, $0.1 \% / \mathrm{s}$ のひずみ速度で，ひずみ約 $0.8 \%$ からシミュ レーション結果と実験結果のずれが見られる。これ は, 式(28)の導出で $n^{\prime}=n$ としたための差であると考 えられる。

図 5 に，一例としてひずみ振幅 $0.5 \%$ ，ひずみ速度 $0.1 \% / \mathrm{s}$ で繰返し真荷を行ったときの実験結果を示 す.図 5 より，1 サイクルめから 2 サイクルめに繰返 し硬化が見られるが，その後は繰返し硬化がほとんど 見られないことがわかる。図 6 に構成モデルでのシミ

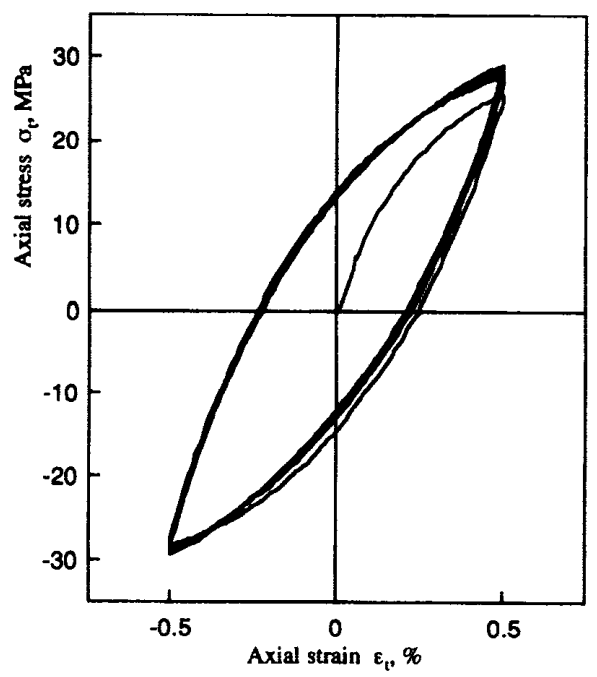

Fig. 5 Cyclic tension compression loading (strain rate: $0.1 \% / \mathrm{s}$, strain amplitude: $0.5 \%$, experiment) 
ュレーション結果を示す．四 6 と図 5 を比較するとシ ミュレーションは実験結果をよく表していることがわ かる。

网 4 㧍よび艮 60 のミュレーションに扔いて, 構成 モデルの材料定数を以下のように定めた。まず，3種 颣(のひずみ速度での)純粋引張実験から $\sigma_{1 \mathrm{im}}$ を求め, そ の值と式(26)より $A_{0}$ および $n$ を算出した。また，材 料定数 $D_{0}, \alpha, c_{1}, m_{0}, \beta, c_{2}, R_{0}, \lambda, c_{3}, C$ は，他の 2 種類 りひずみ速度 $0.001 \% / \mathrm{s}$ 朽よび $0.01 \% / \mathrm{s}$ を含めたす べての繰返し真荷と純粋引張実験に基づいて，最適な 値を試行錯誤的に求めた。 その結果，それらの材料定 数は次式で与えられる。

$$
\begin{aligned}
& D_{0}=33 \mathrm{MP} a, m_{0}=2.60, R_{0}=15.0 \mathrm{MI} \mathrm{a} \\
& \alpha=0.380, \beta=0.100, \lambda=0.0005 \\
& c_{1}=c_{2}=c_{3}=0.0005, \quad A_{0}=1.11 \times 10^{-6}, n=3.23 \\
& C=18.0, c_{4}=0.150 \quad \cdots \cdots \cdots \cdots(30
\end{aligned}
$$

$4 \cdot 3$ ひずみ速度变化を伴う負荷 $4 \cdot 2$ 節で定ぬ た材料定数，式(30)を用いて，ひずみ速度変化を伴う

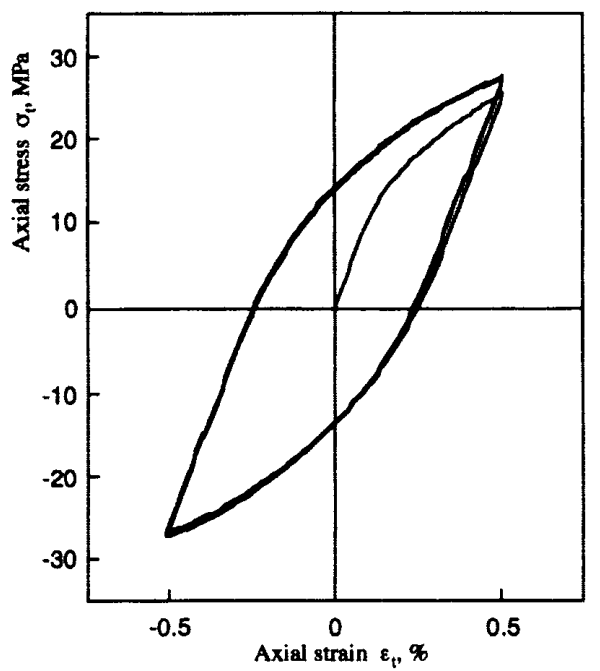

Fig. 6 Cyclic tension compression loading (strain rate: $0.1 \% / \mathrm{s}$, strain amplitude: $0.5 \%$, simulation)

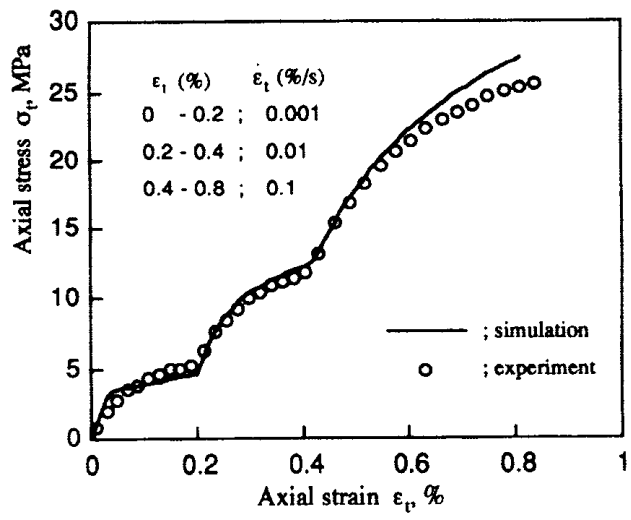

Fig. 7 Pure tension with change of strain rate
負荷のシミュレーションを行った。まず，純粋引張中 にひずみ速度変化がある場命のシミュレーションを試

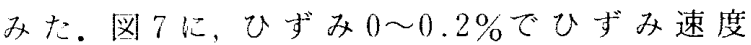

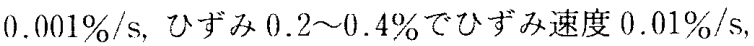
ひずみ $0.4 〜 0.8 \%$ でひずみ速度 $0.1 \% / \mathrm{s}$ と段階的に ひずみ速度を変化させたときの応打ひずみ関係を示

す。図7で○印は実験結果であり，実線はシミュレー ション結果である。

网 8 は、ひずみ振幅 $0.5 \%$ で引張り・迲綃繰返し 負荷を引張側のひずみ速度を $0.01 \% / \mathrm{s}$ ，沓縮側のひず

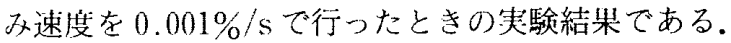
四 8 より, 引張側の硬化量が, 缩側の硬化量に比べ

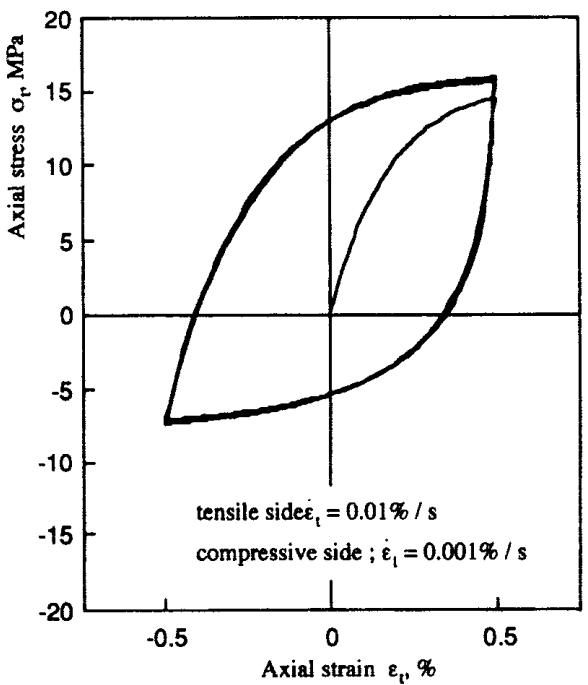

Fig. 8 Cyclic tension compression loading with different strain rate of $0.01 \% / \mathrm{s}$ in tensile side from that of $0.001 \% / \mathrm{s}$ in compressive side (experiment)

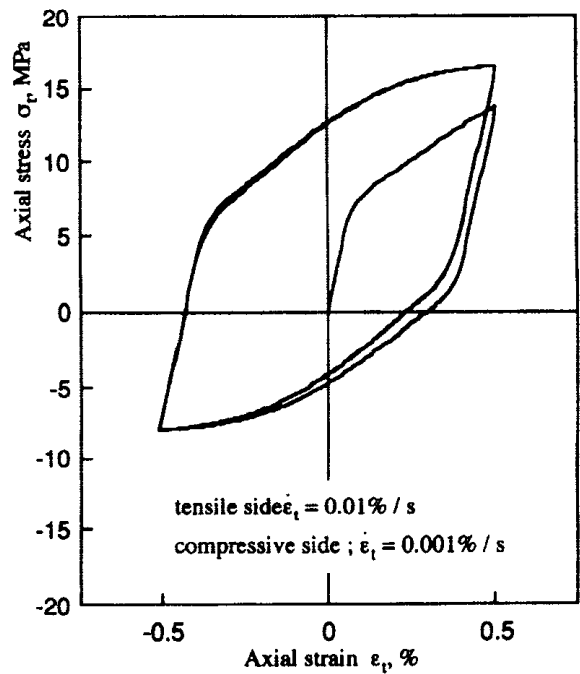

Fig. 9 Cyclic tension-compression loading with different strain rate of $0.01 \% / \mathrm{s}$ in tensile side from that of $0.001 \% / \mathrm{s}$ in compressive side (simulation) 


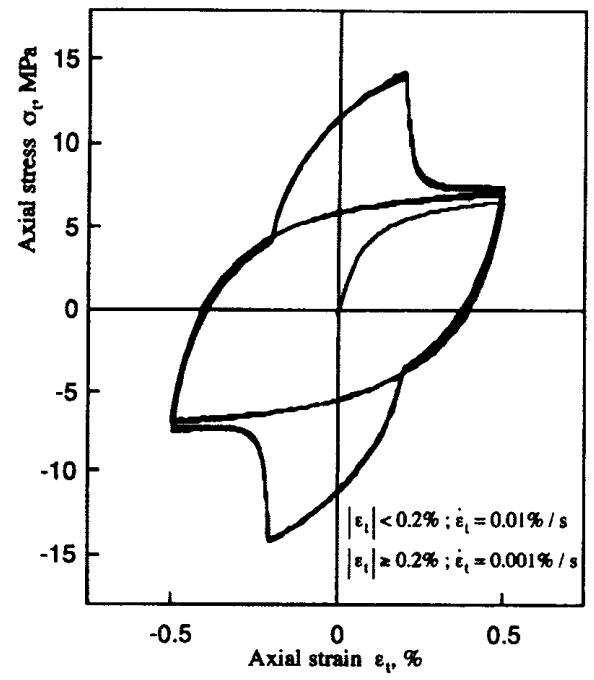

Fig. 10 Cyclic tension-compression loading under strain rate of $0.01 \% / \mathrm{s}$ during $\left|\varepsilon_{t}\right|<0.2$ and $0.001 \% / \mathrm{s}$ during $\left|\varepsilon_{t}\right| \geq 0.2$ (experiment)

て著しく大きいことがわかる．図 8 と同一負荷条件の 繰返し負荷のシミュレーション結果を闵 9 に示す。

図 10 は，ひずみ振幅 $0.5 \%$ ，ひずみ速度 $0.001 \% / \mathrm{s}$ で引張り・王縮繰返し負荷をループが安定するまで与 えた後,ひずみが $-0.2 \%$ から+0.2\%の間で，ひずみ 速度を $0.01 \% / \mathrm{s}$ に変化させて行ったときの実験結果 である. 図 10 から、ひずみ速度が速い範囲では硬化 荲が著しく大きくなることがわかる，また特に，速い ひずみ速度から遅いひずみ速度に変化した場合, 忠 が徐々に隇少し再び遅いひずみ速度での応力ひずみ 曲線に一致する。睬 10 と同一負荷条件での繰返し負 荷のシミュレーション結果を図 11 に示す. 図7〜11 より，いずれの負荷に対してもシミュレーションと実 験結果はよく一致していることがわかる．特に，図 10 で見られるひずみ速度の急変に伴う応力変動の特徵的 な現象を的確に表している。

\section{5. 結言}

本研究では，ひずみ速度依存性が著しい $60 \mathrm{Sn}-40$ $\mathrm{Pb}$ はんだ材の変形挙動を記述するために, 負荷中の クリープ変形を考慮して構成モデルを構築した。そし て、構成モデルのひずみ速度を変化させた純粋引張負 荷および繰返し負荷への適用性について検討した。そ の結果，以下の結諭を得た。

（1）全ひずみ增分を弾性ひずみ増分，塑性ひずみ 増分，クリープひずみ増分の和とした。そして，塑性 ひずみ増分を Prager-Ziegler の移動硬化則，クリ一 プひずみ増分を Norton 則にそれぞれ基づいて算出し 構成モデルを構築した。

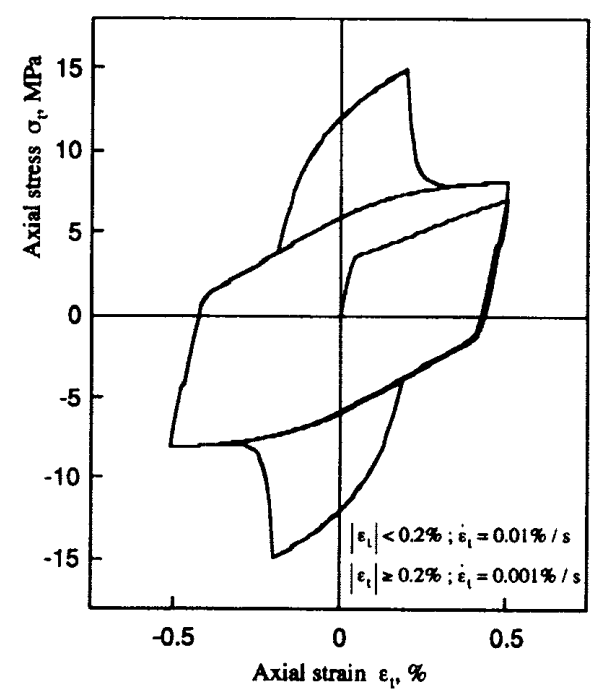

Fig. 11 Cyclic tension compression loading under strain rate of $0.01 \% / \mathrm{s}$ during $\left|\varepsilon_{t}\right|<0.2$ and $0.001 \% / \mathrm{s}$ during $\left|\varepsilon_{t}\right| \geq 0.2$ (simulation)

（2）構成モデルで朋いる材料定数は，3 種類のひ ずみ速度での純粋引張实験と繰返し負荷実験により， 比較的谷易に定められる。

（3）上記（2）で定めた材料定数を用いて純粋引張 中抢よび繰返し負荷中にひずみ速度が変化する負荷の シミュレーションが可能である．特に，ひずみ速度の 急变に伴う応力変動の特徴的な現象を的確に表現でき る.

なお，本研究の一部は，斗成 8 年度文部省科学研究 费補助金基盤研究（B)（2），および，日本学術振與会 特別研究員 (大[1) に交付する科学研究費補助金 (特別 研究員奨励費)の援助を受けた。謝意を表す。

\section{文献}

(1) Solomon, H. D., Fatigue of $60 / 40$ Solder, IEEE CHMT 9, 4 (1986), 423-432.

(2) Guo, Z., Pao, H. Y. and Conrad, H., Plastic deforma tion kinetics of $95.5 \mathrm{Sn}-4 \mathrm{Cu} 0.5 \mathrm{Ag}$ solder joints, Trans. ASME, J. Electronic Packaging, 117 (1995), 100104.

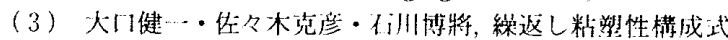
を用いた $60 \mathrm{Sn}-40 \mathrm{~Pb}$ 材引)陂学寿命了測、機諭, 62-594, A (1996), 202208.

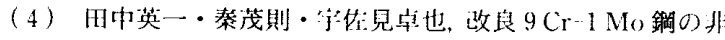
弾性举動の温度低存性上温度变動脽歴低存性，機論，60 $569, \Lambda(1994), 198-204$

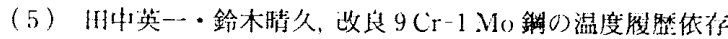
性のモデル化. H本機械学会東游支部第 44 期総会講演会 清演耣文集，(1995 3)，39 40

(6) Freed, A.D. and Walker K.P., Viscoplasticity with Creep and I'lastic Bounds, Int. J. Plasticity, 9(199.3), 21.3 242.

(7) Ohno, N., Kawabata, M. and Naganuma, J., Aging Effects on Monotonic Stress-Paused, and Alternating Creep of Type 304 Stainless Steel, Int. J. Ilasticity, 6 (1990), 315-327. 
（8）河办晶道，塑性さずみによって生じるクリープ異力性の

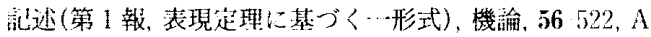
(1990), $326 \cdot 334$

(9) Lee, K. D. and Krempl. E., Uniaxial thermomechanical loading. Numerical experiments using the thermal viscoplasticity theory based on overstress, Eur. J. Mech., A/Solids, 10(1991), 173192.

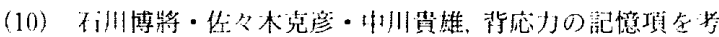
蝶し太綵返し塑性構成式，機論, 59-558, A(1993)，82-88.
(11) Freed, A. D. and Walker, K. P., Viscoplastic model development with an eye towards characterization, ASME, MD-43/AMD-168 (1993), 7188 , Material Parameter Estimation for Modern Consitutive Equations.

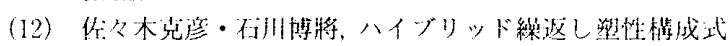

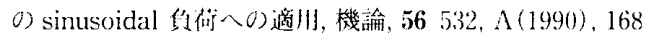
174. 